\title{
ВПРОВАДЖЕННЯ ІННОВАЦІЙНИХ ТЕХНОЛОГІЙ ТА ПЕРСПЕКТИВИ РОЗВИТКУ КАФЕДРИ ПАТОЛОГІЧНОЇ АНАТОМІЇ В УМОВАХ МОДЕРНІЗАЦІЇ І РЕФОРМУВАННЯ ВИЩОЇ МЕДИЧНОЇ ОСВІТИ
}

\author{
Я. Я. Боднар, А. З. Миколенко, В. Д. Волошин, Т. К. Головата, Т. В. Дацко, \\ В. В. Франчук, М. Я. Фурдела, Ю. М. Орел, С. В. Трач Росоловська, П. О. Ваврух, \\ О. В. Андрійчук
} ДВНЗ “Тернопільський держкавний медичний університет імені І. Я. Горбачевського МОЗ України”

\section{THE INNOVATIONAL TECHNOLOGIES IMPLEMENTATION AND PROSPECTS OF DEVELOPMENT OF THE PATHOLOGY DEPARTMENT IN TERMS OF REFORMING AND MODERNIZATION OF HIGH MEDICAL EDUCATION}

\author{
Ya. Ya. Bodnar, A. Z. Mykolenko, V. D. Voloshyn, T. K. Holovata, T. V. Datsko, \\ V. V. Franchuk, M. Ya. Furdela, Yu. M. Orel, S. V. Trach Rosolovska, P. O. Vavrukh, \\ O. V.Andriychuk \\ SHEI "Ternopil State Medical University by I. Ya. Horbachevsky of MPH of Ukraine”
}

\begin{abstract}
У статті висвітлено якість впровадження інноваційних технологій, результатів наукових розробок, нових методичних підходів до викладання профільних дисциплін на кафедрі патологічної анатомії з секційним курсом та судової медицини Тернопільського державного медичного університету ім. І. Я. Горбачевського та наведено напрямки перспектив розвитку кафедри в умовах реформування медичної освіти та інтеграції у світовий освітній простір.
\end{abstract}

The quality of innovational technologies implementation, results of scientific research, new methodical approaches to the teaching of subjects at the Department of Pathology and Forensic Medicine of Ternopil State Medical University by I. Ya. Horbachevsky are described in the article. The particular attention is given to the new perspective of development of the department in terms of reforming medical education and integration into the global educational community.

Вступ. Постійний розвиток медичної освіти обумовлений впровадженням сучасних методів керування пізнавальним процесом, який передбачає знання і володіння студентами патогенезу та морфологічного субстрату хвороб $[1,2]$. Впровадження сучасних технологій дозволяє більш результативно використовувати час для засвоєння практичних навичок, підвищувати якість отриманих студентами знань $[2,3]$. За останні роки патологічна анатомія все більше вдосконалює методи та рівні морфологічних досліджень, що надає можливість пояснити механізми ініціації патологічних процесів, обгрунтувати на молекулярному рівні зміни у доклінічному періоді захворювань.

Основна частина. Основним завданням кафедри патологічної анатомії з секційним курсом та судової медицини є вдосконалення прикладного вивчення патологічних процесів i, через клініко-морфологічний аналіз, навчити студентів морфологічних основ хво- роб, вірно оцінювати їхні клінічні прояви та вирішувати питання судово-медичної експертизи.

За останні роки співробітниками кафедри впроваджені в навчальний процес нові технології та методичні підходи до викладання дисциплін згідно з європейськими вимогами реформування медичної освіти. Навчальні кімнати кафедри оснащені мультимедійною технікою і плазмовими телевізорами, що забезпечує демонстрацію мікропрепаратів і аналіз патологічних змін для усієї аудиторії. Під час занять студенти мають можливість використовувати мультимедійні презентації лекцій, матеріали самопідготовки, електронні таблиці, навчальні відеофільми, розміщені на веб-порталі університету, користуватися інформацією, отриманою з глобальної мережі Інтернет. Розроблена система цілеспрямованого керування пізнавальним процесом на основі проблемно-пошукового навчання, що знайшло своє відобра-

(ㄱ Я. Я. Боднар, А. З. Миколенко, В. Д. Волошин та ін. 
ження у впровадженні Z-системи і єдиного навчального дня. Кінцевою метою запровадження новітніх педагогічних технологій, зокрема методики єдиного дня, є максимальне спрямування студентів на оволодіння практичними навичками, як на доаудиторному так і аудиторному етапах. Удосконалення самостійної роботи студентів здійснюється шляхом впровадження в навчальний процес адаптованих до існуючих вимог альбомів, у яких на першому етапі студенти виконують теоретичні завдання, а на другому - практичні, оволодіваючи навичками опису патологічних процесів на макроскопічному та мікроскопічному рівнях, позначаючи на рисунках найбільш характерні прояви морфологічних змін на тканинному та клітинному рівнях. Неупереджено оцінити набуті студентами практичні уміння і навички дозволяє об' єктивний структурований клінічний іспит, елементом якого є вивчення мікроскопічних препаратів з формулюванням патогістологічного висновку.

За останні 5 років на кафедрі був реставрований та доповнений один з найбільших в Україні музей макропрепаратів, експозиція якого стала доступнішою для вивчення студентами проявів різних патологічних процесів та є частиною щоденних практичних занять. Експонати систематизовані за змістовими модулями патоморфології та судової медицини. Навчальний фонд кафедри доповнено новими мікропрепаратами, особливо із використанням гістохімічних методів забарвлення тканин. Мікропрепарати використовуються не тільки на практичних заняттях як ілюстративний матеріал, а й молодими асистентами та студентами-гуртківцями для вдосконалення навичок патогістологічної діагностики.

Значна увага надається вивченню майбутніми лікарями особливостей судово-медичної травматології, діагностиці та експертній оцінці ушкоджень від дії тупих і гострих предметів, вогнепальної зброї. Для кращого засвоєння студентами навчального матеріалу та, посилюючи зв’ язок навчання з практикою, на кафедрі створено судово-медичний музей. В ньому демонструються стенди із взірцями різноманітних травмуючих предметів, зразки вогнепальної зброї в сукупності з макропрепаратами частин тіла та одягом, на яких відображені важливі експертно-діагностичні ознаки вогнепальних ушкоджень. Також представлені 2 унікальні макети, на яких ретельно відтворені усі деталі місця події, з демонстрацією трупа загиблої особи, особливостей одягу, ушкоджень та речових доказів.

У навчальний процес також впроваджуються результати наукових розробок співробітників кафедри.
Основним напрямком наукової діяльності є вивчення морфофункціональних змін серцево-судинної системи, зумовлених різними екзо- та ендогенними чинниками, зокрема при цукровому діабеті, хронічній алкогольній інтоксикації тощо. Протягом останнього п'ятиріччя на кафедрі виконуються планові комплексні науково-дослідницькі роботи: “Вивчення патогенетичної ролі мікробіологічних чинників на перебіг соматичної патології у дітей”. Завершено наукову роботу “Клініко-морфологічні зміни систем організму при цукровому діабеті і тиреопатіях у віковому аспекті” (2009 р.). Сумісно із кафедрою патологічної анатомії Івано-Франківського національного медичного університету та Інституту клінічної патології Львівського національного медичного університету імені Данила Галицького підготовлено до видання атлас патогістології, призначений як для студентів ВН3, так і для практичних лікарів-патоморфологів.

Важливе місце у роботі співробітників кафедри займає консультативно-діагностична та експертна робота, яка виконується на базах Тернопільського обласного патологоанатомічного бюро та Тернопільського обласного бюро судово-медичної експертизи. Як показує практика, більшу частину свого робочого часу лікар-патологоанатом витрачає на прижиттєву діагностику захворювань, використовуючи аналіз інтраопераційних, пункційних та аспіраційних біопсій.

У 2011 році за ініціативою ректора університету члена-кореспондента НАМН України, доктора медичних наук, професора Л. Я. Ковальчука на базі університетської лікарні створено лабораторію інтраопераційної гістологічної експрес-діагностики. Лабораторія розміщена в окремому, сучасно обладнаному, приміщенні поряд із операційним блоком, що дає можливість оперативно провести морфологічний аналіз тканин, видалених в процесі оперативного втручання. Сучасні телекомунікаційні технології дозволяють транслювати гістологічне зображення із лабораторії на кафедру в режимі реального часу. Спільне вивчення препаратів завідувачем, викладачами та студентами дає змогу швидко надати максимально об' єктивний і повний інтраопераційний патогістологічний висновок і наочно продемонструвати місце патанатомії в діагностичному процесі. У багатьох випадках це має вирішальне значення при виборі подальшого обсягу і тактики лікування.

Аналізуючи досягнуте, співробітники кафедри патологічної анатомії з секційним курсом та судової медицини організували та провели дискусії, де були обговорені й затверджені перспективи розвитку педагогічної, наукової та лікувальної роботи на кафедрі. 
Одним 3 перспективних напрямків вважається метод вирощування тканинних та клітинних культур, завдяки якому значно розширюються можливості наукових досліджень і діагностики, оскільки можна оцінити не тільки морфологічні й біохімічні зміни, але i їх поведінку залежно від мікрооточення. Крім того, було запропоновано реалізацію таких проектів:

- створити каталог зображень патологічних процесів, отриманих при УЗД, рентгенографіi, ангіографіi, урографії тощо, i розробити алгоритм їх вивчення студентами у поєднанні із макроскопічними змінами;

- створити навчальні відеофільми з усіх змістових модулів патоморфології та судової медицини з озвученням українською, російською та англійською мовами;

- запровадити методи імуногістохімічної діагностики патологічних процесів в наукових та діагностичних цілях;

\section{Література}

1. Ковальчук Л. Я. Впровадження новітніх методик і систем навчального процесу в Тернопільському державному медичному університеті ім. І. Я. Горбачевського / Л. Я. Ковальчук // Медична освіта. -2009. -№ 2. -С. 10-14.

2. Інноваційні технології у навчальному процесі в державному закладі “Луганський державний медичний університет” / В. К. Івченко, В. В. Сімрок, М. С. Смірнов,
- створити колекцію мікропрепаратів типових для нашого регіону захворювань і пухлин, які рідко зустрічаються, та вроджених вад.

Висновки: 1. Запровадження нового типу керованої системи проблемного вивчення патоморфології та судової медицини дозволяє створити необхідну пізнавальну ситуацію, забезпечити умови для розв'язання проблемних завдань, підвищити ефективність засвоєння практичних навичок, а в підсумку підвищити рівень клініко-морфологічного мислення студента - майбутнього фахівця.

2. За допомогою використання новітніх комп'ютерних технологій у вивченні патологічної анатомії та судової медицини забезпечується зворотний зв'язок викладач-студент. Окрім цього телекомунікаційні програми дають можливість забезпечити дистанційне навчання іноземних студентів Греції та США в режимі реального часу.

В. М. Сенчій // Медична освіта. - 2011. - № 2. - С. 66-68.

3. Ковальчук Л. Я. Результати реалізації концепції розвитку Тернопільського державного медичного університету iм. І. Я. Горбачевського на шляху його входження у світовий освітній простір / Л. Я. Ковальчук // Медична освіта.2011.-№2.-C. 12-19. 